\title{
Atmospheric Nitrate Deposition, Microbial Community Composition, and Enzyme Activity in Northern Hardwood Forests
}

\author{
Jared L. DeForest,* Donald R. Zak, Kurt S. Pregitzer, and Andrew J. Burton
}

\begin{abstract}
On a global scale, human activity has increased the atmospheric input of $\mathrm{NO}_{3}^{-}$to many terrestrial ecosystems. Anthropogenic $\mathrm{NO}_{3}^{-}$ may be a potent modifier of ecosystem function, especially in temperate forests that are sometimes $\mathbf{N}$ limited. However, the impact of chronic $\mathbf{N}$ deposition on soil microorganisms is still poorly understood. Nitrate entering Lake States forests is rapidly assimilated by the microbial community and it is subsequently released as $\mathrm{NH}_{4}^{+}$. Because high levels of $\mathrm{NH}_{4}^{+}$inhibit the activity of lignin-degrading soil fungi, we reasoned that chronic $\mathbf{N}$ additions could alter the composition and function of heterotrophic microbial communities in soil, and hence the ecosystem-level processes they mediate. We tested our hypothesis in four northern hardwood ecosystems in northern Michigan, which received experimental $\mathrm{N}$ additions $\left(30 \mathrm{~kg} \mathrm{NO}_{3}^{-}-\mathrm{N} \mathrm{ha}^{-1} \mathrm{yr}^{-1}\right)$ during the past 8 yr. We quantified microbial community function by measuring the activity of extracellular enzymes involved in plant litter degradation and described microbial community composition using phospholipid fatty acid (PLFA) analysis. Chronic $\mathbf{N}$ additions significantly suppressed $\beta$-glucosidase activity by $24 \%$ in mineral soil and suppressed phenol oxidase activity by $35 \%$ in surface litter. We found no evidence that chronic $\mathbf{N}$ additions altered microbial community composition; $\mathrm{NO}_{3}^{-}$addition did not alter the relative abundance of bacterial, actinomycetal, fungal, or protozoan PLFAs. However, $\mathrm{NO}_{3}^{-}$additions significantly reduced microbial biomass by $18 \%$ relative to the control treatment. Results indicate that $\mathrm{N}$ additions broadly suppressed all microbial groups, not just the activity and abundance of lignin-degrading fungi.
\end{abstract}

$\mathrm{H}$ UMAN ACTIVITY has globally increased the amount of $\mathrm{N}$ entering terrestrial ecosystems from the atmosphere (Galloway, 1998). The northeastern and east central USA receives the greatest amounts of $\mathrm{N}$ deposition in North America (Fenn et al., 1998), ranging from 2 to 16 times background levels (Galloway et al., 1984). The impact of anthropogenic $\mathrm{N}$ deposition on temperate forests is a primary concern, because increases in soil $\mathrm{N}$ availability have the potential to alter species diversity, plant community composition, and ecosystem function (Vitousek et al., 1997; Aber et al., 1998; Boxman et al., 1998; Gundersen et al., 1998).

There are reasons to expect that anthropogenic $\mathrm{N}$ deposition also could directly or indirectly alter the composition and function of soil microbial communities. Plant litter provides the primary energy source for heterotrophic microbial growth in soil, and changes in the amount and type of organic substrates entering soil in-

J.L. DeForest and D.R. Zak, School of Natural Resources \& Environment, 430 E. University, Univ. of Michigan, Ann Arbor, MI 481091115; K.S. Pregitzer and A. J. Burton, School of Forest Resources and Environmental Science, Michigan Technological Univ., 1400 Townsend Dr., Houghton, MI 49931. Received 20 Nov. 2002. *Corresponding author (jdefores@umich.edu).

Published in Soil Sci. Soc. Am. J. 68:132-138 (2004).

(c) Soil Science Society of America

677 S. Segoe Rd., Madison, WI 53711 USA duced by $\mathrm{N}$ deposition could indirectly influence the composition and function of microbial communities. Alternatively, anthropogenic $\mathrm{N}$ deposition could directly modify soil microbial communities by suppressing the activity of lignin-degrading fungi (Berg, 1986; Fog 1988; Dix and Webster, 1995), thus potentially lowering their abundance and diminishing the overall capacity of microbial communities to degrade lignin and other polyphenols (Carreiro et al., 2000). Such a response could alter rates of soil organic matter formation and the release of plant nutrients from litter. Relatively high levels of $\mathrm{NH}_{4}^{+}$in soil suppress lignin oxidation (Keyser et al., 1978), and the rapid microbial assimilation of anthropogenic $\mathrm{NO}_{3}^{-}$and its subsequent release as $\mathrm{NH}_{4}^{+}$(Zogg et al., 2000) indicates that anthropogenic $\mathrm{NO}_{3}^{-}$could potentially suppress the abundance and activity of lignindegrading fungi.

We have experimentally manipulated $\mathrm{NO}_{3}^{-}$deposition in four northern hardwood stands in Michigan's Lower and Upper Peninsula. During the past $8 \mathrm{yr}$, the addition of $30 \mathrm{~kg} \mathrm{NO}--\mathrm{N} \mathrm{ha}^{-1} \mathrm{yr}^{-1}$ has significantly increased the export of dissolved organic C (DOC) and dissolved organic N (DON) from these forest stands (Pregitzer et al., 2003), suggesting a change in litter chemistry, a change in microbial community function, or both. Here, we investigate the alternative that longterm $\mathrm{NO}_{3}^{-}$deposition has altered microbial community function and composition by suppressing fungal activity and abundance. During the course of one growing season, we measured extracellular enzyme activity to gain insight into microbial community function, and we assessed community composition using PLFA analysis. Our primary objective was to determine if chronic $\mathrm{N}$ additions have altered the composition and function of the heterotrophic microbial community.

\section{MATERIALS AND METHODS}

\section{Study Area}

Four study sites were established along a 500-km climatic and $\mathrm{N}$ deposition gradient extending from northwest Upper Michigan to central Lower Michigan (Fig. 1). The study sites encompass the geographic extent of sugar maple (Acer saccharum Marsh.)-dominated northern hardwood forest in Michigan, and they are similar in composition, history, structure, and soil development (Table 1; Burton et al., 1993). The soils are classified as sandy, mixed, frigid Typic and Alfic Haplorthods (MacDonald et al., 1995). At each of the four study sites, we established six 30 by 30 m experimental plots. Three plots served as controls receiving ambient levels of $\mathrm{N}$ deposition, whereas the remaining three plots received ambi-

Abbreviations: DOC, dissolved organic carbon; DON, dissolved organic nitrogen; FAME, fatty acid methyl esters; PLFA, phospholipid fatty acid. 


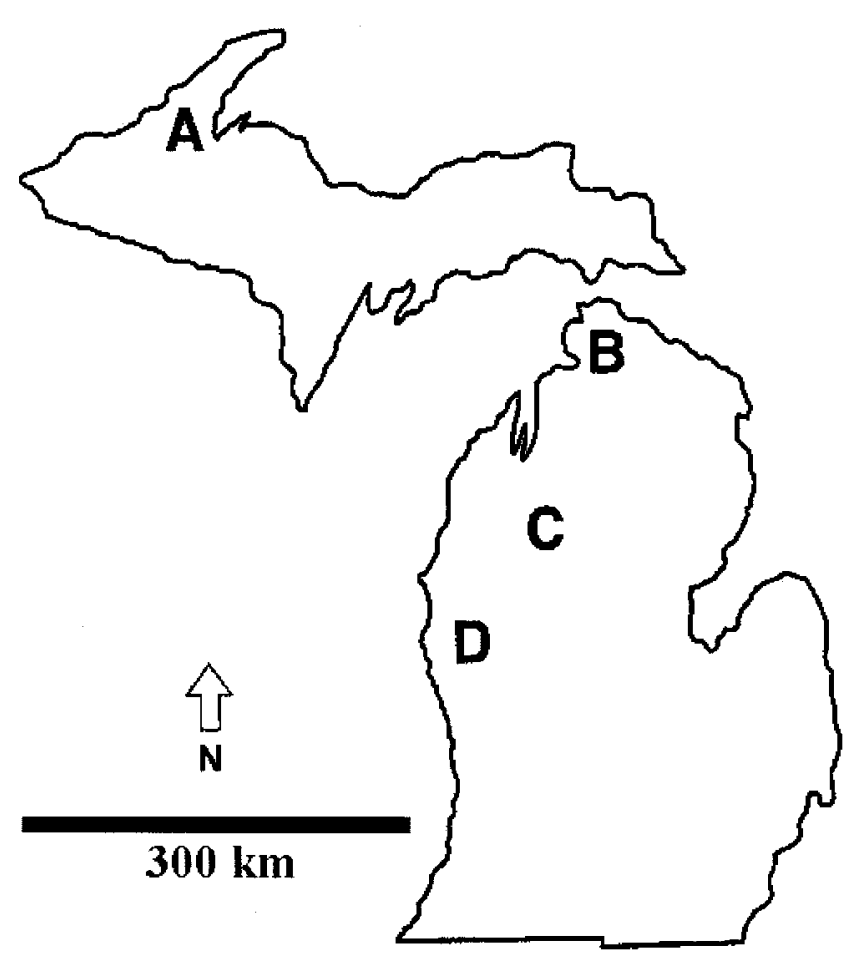

Fig. 1. Distribution of the four northern hardwood sites along a 500km climatic gradient in Michigan, USA. These stands span the geographic distribution of sugar-maple dominated northern hardwood forests in the upper Lake States region.

ent $\mathrm{N}$ deposition plus chronic atmospheric $\mathrm{N}$ deposition (30 $\mathrm{kg} \mathrm{NO}_{3}^{-}-\mathrm{N} \mathrm{ha}^{-1} \mathrm{yr}^{-1}$ ). The $\mathrm{NO}_{3}^{-}$was applied six times during the growing season as small $\mathrm{NaNO}_{3}$ pellets. We used $\mathrm{NO}_{3}^{-}$ because it is the most common form of $\mathrm{N}$ that is atmospherically deposited in this region (Galloway, 1998; MacDonald et al., 1995).

\section{Field Sampling}

In each site, we collected eight forest floor/mineral soil cores (2-cm diam. and 10-cm deep) in all six plots. We separated forest floor ( $\mathrm{Oe}$ and $\mathrm{Oa}$ ) from mineral horizons ( $\mathrm{A}$ and E) in each core, and then composited the eight forest floor samples and eight mineral samples in each plot. This provided us with one composite forest floor sample and one composite mineral horizon sample in each control and $\mathrm{NO}_{3}^{-}$amended plot. Collection of forest floor and mineral soil occurred in early June, mid July, and late October 2001.
Table 2. Extracellular enzymes involved in plant litter degradation that were measured in northern hardwood ecosystems receiving experimental $\mathrm{NO}_{3}^{-}$additions.

\begin{tabular}{ll}
\hline Enzyme & \multicolumn{1}{c}{ Substrate } \\
\hline Acid Phosphatase & Phosphate Esters \\
N-acetyl-glucosaminidase & Chitin \\
$\alpha$-glucosidase & Starch \\
$\beta$-glucosidase & Cellulose \\
Cellobiohydrolase & Cellulose \\
$\beta$-xylosidase & Hemicellulose \\
Peroxidase & Lignin \\
Phenol Oxidase & Lignin \\
\hline
\end{tabular}

\section{Microbial Community Function and Composition}

\section{Extracellular Enzyme Analysis}

In forest floor and mineral soil, we measured the activity of enzymes responsible for the degradation of four common plant litter compounds, plus chitin and organic phosphate (Table 2). Enzyme activity was measured on field-fresh samples within $2 \mathrm{~h}$ of collection. We prepared enzyme assays by blending $1 \mathrm{~g}$ of forest floor or mineral soil in $150 \mathrm{~mL}$ of 50 $\mathrm{m} M$ acetate buffer at $\mathrm{pH} 5.0$, which was similar to field soil pH (Saiya-Cork et al., 2002). Activities of non-ligninolytic enzymes were fluorometrically measured in 96-well plates using methylumbelliferone (MUB)-linked model substrates (Saiya-Cork et al., 2002). Forest floor and mineral soil assayed for $\mathrm{N}$-acetylglucosaminidase (NAGase) and phosphatase activity were incubated for $0.5 \mathrm{~h}$ at $25^{\circ} \mathrm{C}$, whereas the remaining non-ligninolytic enzymes ( $\alpha$-glucosidase, $\beta$-glucosidase, cellobiohydrolase, $\beta$-xylosidase) were incubated for $2 \mathrm{~h}$ at $25^{\circ} \mathrm{C}$ (Saiya-Cork et al., 2002). At the termination of the assay, we added $25 \mu \mathrm{L}$ of $\mathrm{NaOH}(0.2 M)$ to each well to enhance fluorescence, which was measured using F-max fluorimeter (Molecular Devices Corp., Sunnyvale, CA). Excitation energy was $355 \mathrm{~nm}$ and emission was measured at $460 \mathrm{~nm}$ (SaiyaCork et al., 2002).

We measured peroxidase and phenol oxidase activity using L-dihydroxyphenylalanine (L-DOPA) (Saiya-Cork et al., 2002). After incubating the samples for $18 \mathrm{~h}$ at $25^{\circ} \mathrm{C}$ in 96 -well plates, the optical density $(460 \mathrm{~nm})$ of the oxidized reaction product was measured on a spectrophotometer (Bio-Tek Instruments, Winooski, VT).

\section{Phospholipid fatty acid Analysis}

Phospholipid fatty acid analysis was used to measure the biomass and abundance of bacteria, actinomycetes, fungi, and protozoa in control and $\mathrm{NO}_{3}^{-}$amended plots (Vestal and White, 1989; Tunlid and White, 1992). If chronic $\mathrm{NO}_{3}^{-}$deposi-

Table 1. Site, climatic, overstory, and soil characteristics of four sugar maple stands receiving experimental $\mathrm{NO}_{3}^{-}$additions.

\begin{tabular}{|c|c|c|c|c|}
\hline Forest Characteristics & Site A & Site B & Site $\mathbf{C}$ & Site D \\
\hline \multicolumn{5}{|c|}{ Climate } \\
\hline Latitude, $\mathbf{N}$ & $46^{\circ} 52^{\prime}$ & $\mathbf{4 5}^{\circ} 33^{\prime}$ & $44^{\circ} 23^{\prime}$ & $43^{\circ} 40^{\prime}$ \\
\hline Longitude, W & $8^{\circ} 53^{\prime}$ & $84^{\circ} 51^{\prime}$ & $\mathbf{8 5}^{\circ} \mathbf{5 0}^{\prime}$ & $86^{\circ} 09^{\prime}$ \\
\hline Mean annual precipitation, $1994-2001, \mathrm{~mm}$ & 821 & 828 & 856 & 793 \\
\hline Mean annual temperature, 1994-2001, $\mathrm{C}^{\circ}$ & 4.8 & 6.1 & 6.9 & 7.6 \\
\hline Wet plus dry $\mathrm{NO}_{3}^{-}-\mathrm{N}$ deposition, $\mathrm{kg} \mathrm{ha}^{-1} \mathbf{y r}^{-1}$ & 3.8 & 5.8 & 7.8 & 7.6 \\
\hline Wet plus dry total $\mathrm{N}$ deposition, $\mathrm{kg} \mathrm{ha}^{-1} \mathbf{y r}^{-1}$ & 6.8 & 9.1 & 11.7 & 11.8 \\
\hline Total N deposited, 1994-2001, $\mathrm{kg} \mathrm{ha}^{-1} \dagger$ & 290 & 310 & 334 & 335 \\
\hline \multicolumn{5}{|c|}{ Vegetation and Soil } \\
\hline Overstory age, 2001 & 94 & 88 & 89 & 93 \\
\hline Total basal area, $2001, \mathrm{~m}^{2} \mathrm{ha}^{-1}$ & 35 & 33 & 33 & 36 \\
\hline Overstory biomass, $\mathrm{Mg} \mathrm{ha}^{-1}$ & 261 & 261 & 274 & 234 \\
\hline Sugar maple biomass, 2001, \% & 91 & 86 & 79 & 71 \\
\hline Net $\mathbf{N}$ mineralization, $\mu \mathrm{g} \mathrm{N} \mathbf{g}^{-1} \uparrow$ & 52 & 76 & 81 & 55 \\
\hline
\end{tabular}

$\uparrow$ The sum of naturally deposited $\mathbf{N}$ and added $\mathbf{N}$.

$\uparrow$ Zogg et al. (1996). 


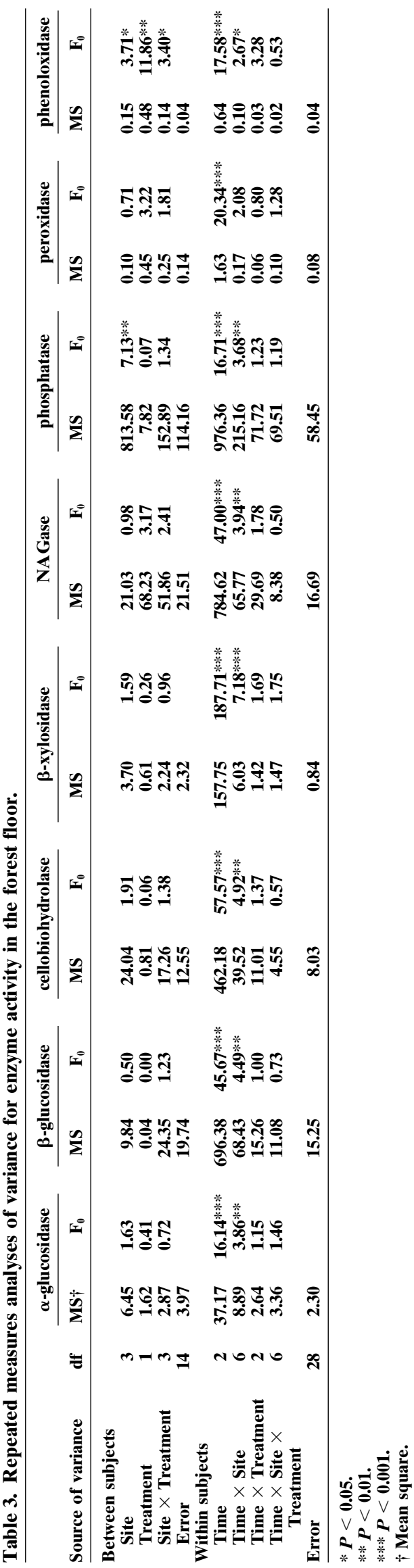

tion lowered the abundance of lignin degrading soil fungi, then we expected to observe a significance change in the relative abundance of fungal biomarkers. From each of the field-fresh homogenized mineral soil samples, we removed and freeze-dried a 40-g subsample for PLFA analysis. We

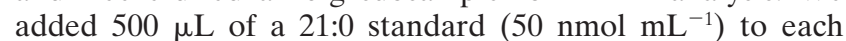
sample before analysis to determine recovery. We used a solution containing $10 \mathrm{~mL}$ of $\mathrm{CH}_{3} \mathrm{OH}, 5 \mathrm{~mL}$ of $\mathrm{CH}_{3} \mathrm{Cl}$, and $4 \mathrm{~mL}$ of $\mathrm{PO}_{4}^{3-}$ buffer to extract total lipids from $5 \mathrm{~g}$ of freeze-dried soil (White et al., 1979). The polar and non-polar lipids were separated by silicic acid chromatography. The separated polar lipids were subjected to an alkaline $\mathrm{CH}_{3} \mathrm{Cl}-\mathrm{CH}_{3} \mathrm{OH}$ solution to form fatty acid methyl esters (FAMEs) (Guckert et al., 1985). Fatty acid methyl esters were separated using gas chromatography and quantified using a Finnigan Delta plus mass spectrometer with a GC/C III interface (Thermofinnigan, Bremen, Germany). A 19:0 internal standard was added to each sample to determine analytical precision. The concentration of sample FAMEs was determined by a regression equation based from a standard solution containing five common FAMEs (10Me16:0, 12:0, cy19:0a, i15:0, 15:0) of known concentrations analyzed after every fifth sample. We quantified 21 PLFA biomarkers, indicative of bacteria, actinomycetes, fungi, and protozoa, and we used total PLFA as a measure of viable microbial biomass.

\section{Statistical Analysis}

We used a two-way, repeated-measures analysis of variance to determine the effect of $\mathrm{NO}_{3}^{-}$deposition on microbial community function and composition. Nitrate treatment and site were fixed effects in our model. We used Tukey's post-hoc test to determine significant differences among means. Significance for all statistical analysis was accepted at $\alpha=0.05$.

\section{RESULTS Forest Floor Enzyme Activity}

Nitrate addition had a significant main effect on phenol oxidase in the forest floor; the mean rate in $\mathrm{NO}_{3}^{-}$ amended plots $\left(781 \pm 137 \mathrm{nmol} \mathrm{g}^{-1} \mathrm{~h}^{-1}\right.$; Mean $\left.\pm \mathrm{SE}\right)$ was significantly lower than that in the control treatment (1198 $\pm 152 \mathrm{nmol} \mathrm{g}^{-1} \mathrm{~h}^{-1}$; Table 3). Time also had a significant effect on phenol oxidase activity (Table 3 ), wherein activity doubled for the October sampling date (approximately $1600 \mathrm{nmol} \mathrm{g}{ }^{-1} \mathrm{~h}^{-1}$ ), as compared with June and July (approximately $750 \mathrm{nmol} \mathrm{g}^{-1} \mathrm{~h}^{-1}$ ). However, closer inspection of interactions between site and treatment shows that phenol oxidase was only suppressed in the two northern-most sites (Sites A and B), whereas we observed little suppression of phenol oxidase in the two southern most sites (Fig. 2). Peroxidase activity also was reduced by $\mathrm{NO}_{3}^{-}$addition $(32 \%$ decrease), but this response was not significant (Table 4).

Nitrate addition had no effect on $\alpha$-glucosidase, cellobiohydrolase, $\beta$-xylosidase, or acid phosphatase (Table 4). Except for forest floor phenol oxidase, none of the other enzymes measured in forest floor exhibited a change in activity due to $\mathrm{NO}_{3}^{-}$addition (Table 3 ). The activity of all enzymes significantly increased with time, making time a significant effect in our analysis (Table 3 ). 


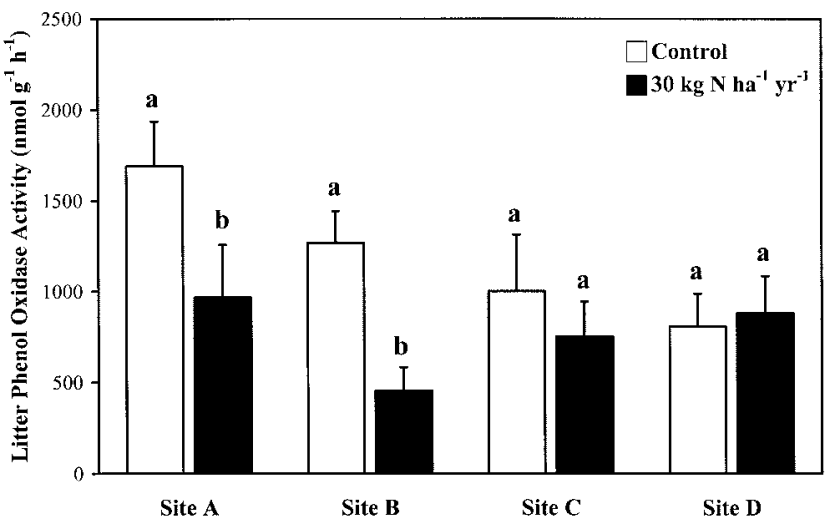

Fig. 2. The influence of site and $\mathrm{N}$ addition on phenol oxidase activity in the forest floor. Means within a site with the same letter are not significantly different $(\alpha=0.05)$. Error bars indicate standard error of the mean $(n=9)$.

\section{Mineral Soil Enzyme Activity}

Chronic $\mathrm{NO}_{3}^{-}$additions also reduced microbial activity in mineral soil. There was a significant interaction between time and treatment on peroxidase activity in mineral soil, wherein $\mathrm{NO}_{3}^{-}$additions reduced peroxidase activity by $50 \%$ in June (Fig. 3). However, this effect dissipated in July and October, resulting in a nonsignificant treatment main effect (Table 5). Nitrate deposition had a significant main effect on $\beta$-glucosidase activity, and rates were reduced from $70 \pm 9 \mathrm{nmol} \mathrm{g}^{-1} \mathrm{~h}^{-1}$ in control plots to $53 \pm 7 \mathrm{nmol} \mathrm{g}^{-1} \mathrm{~h}^{-1}$ in plots receiving chronic $\mathrm{NO}_{3}^{-}$additions. Most of the enzymes measured in soil, except $\alpha$-glucosidase and phenol oxidase, significantly increased their activity throughout the growing season, making time a significant main effect (Table 5). $\beta$-glucosidase was the only enzyme in mineral soil that was significantly suppressed by chronic $\mathrm{NO}_{3}^{-}$additions across all times and sites (Table 5). Peroxidase and phenol oxidase in soil were reduced by $\mathrm{NO}_{3}^{-}$additions (Table 4), but not significantly.

\section{PLFA Analysis}

Chronic $\mathrm{NO}_{3}^{-}$additions significantly lowered total extracted PLFA, indicating a general decline in microbial biomass. Treatment was a significant main effect for total PLFA $(P=0.039)$ in that microbial biomass was suppressed in $\mathrm{NO}_{3}^{-}$amended plots from $233.0 \pm 20.8$

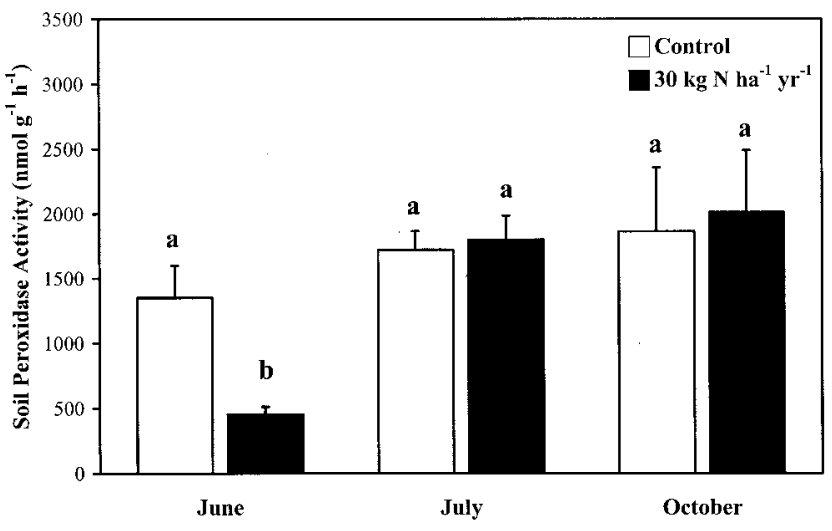

Fig. 3. The influence of time and $\mathbf{N}$ addition on peroxidase activity in mineral soil. Means within a sampling time with the same letter are not significantly different $(\alpha=\mathbf{0 . 0 5})$. Error bars indicate standard error of the mean $(n=18)$.

$\mathrm{nmol} \mathrm{g}^{-1}$ in the control treatment and $190.0 \pm 15.4 \mathrm{nmol}$ $\mathrm{g}^{-1}$ in $\mathrm{NO}_{3}^{-}$amended plots. Time was a significant main effect $(P<0.001)$, and mean total PLFA increased from $117 \pm 9 \mathrm{nmol} \mathrm{g}^{-1}$ in June to $265 \pm 17 \mathrm{nmol} \mathrm{g}^{-1}$ in October. However, we found no significant differences in total PLFA among sites $(P>0.10)$. Interactions between time and treatment, and between site and treatment, had no influence on total PLFA $(P>0.32)$. While total PLFA changed due to time, microbial community composition remained consistent. $\mathrm{NO}_{3}^{-}$additions did not alter the proportion of bacterial, actinomycetal, fungal, or protozoan PLFA (Fig. 4).

\section{DISCUSSION}

Chronic $\mathrm{NO}_{3}^{-}$additions have the potential to directly modify microbial community composition and function by suppressing the abundance and activity of fungi, which degrade lignin. Alternatively, chronic nitrate deposition could alter the production and biochemical composition of plant litter, and, in turn, substrate availability for heterotrophic microbial communities. Our results indicate that chronic $\mathrm{NO}_{3}^{-}$deposition significantly lowered microbial biomass, but it did not alter the proportion of bacterial, actinomycetal, fungal, and protozoan PLFAs in soil. We also observed a significant suppression of phenol oxidase in litter and $\beta$-glucosidase in mineral soil, suggesting the chronic $\mathrm{NO}_{3}^{-}$deposition

Table 4. The influence of $\mathbf{N}$ additions on mean enzyme activity. $\dagger$

\begin{tabular}{|c|c|c|c|c|c|c|}
\hline & \multicolumn{2}{|c|}{ Mean forest floor enzyme activity } & \multirow[b]{2}{*}{ Change } & \multicolumn{2}{|c|}{ Mean mineral soil enzyme activity } & \multirow[b]{2}{*}{ Change } \\
\hline & Control & Fertilized & & Control & Fertilized & \\
\hline & & & $\%$ & nI & -1 & $\%$ \\
\hline$\alpha$-glucosidase & 34.2 (4.6) & $43.9(5.9)$ & 22.1 & $2.2(0.4)$ & $2.3(0.4)$ & 4.3 \\
\hline$\beta$-glucosidase & $719.0(53.8)$ & 759.7 (76.5) & 5.4 & $69.9(9.1)$ & $53.2(6.5)$ & $-23.9^{*}$ \\
\hline cellobiohydrolase & $218.6(26.0)$ & 233.4 (32.3) & 6.3 & $8.9(1.2)$ & $8.1(0.9)$ & -9.0 \\
\hline$\beta$-xylosidase & 89.2 (8.3) & $97.7(9.9)$ & 8.7 & $33.1(5.1)$ & 31.9 (3.2) & -3.6 \\
\hline NAGase: & 463.9 (62.1) & 369.4 (45.0) & -20.4 & $20.2(2.6)$ & $17.3(1.9)$ & -14.3 \\
\hline phosphatase & 2094.0 & 2283.8 (243.9) & 8.3 & 285.3 (24.7) & 303.7 (24.6) & 6.1 \\
\hline peroxidase & $1684.9(279.8)$ & $1147.5(207.6)$ & -31.9 & 1640.5 (223.5) & $1387.2(240.0)$ & -15.4 \\
\hline phenol oxidase & 1197.7 (152.4) & 780.9 (136.7) & $-34.8^{*}$ & 403.9 (72.8) & $385.5(96.3)$ & -4.6 \\
\hline
\end{tabular}

* $\boldsymbol{P}<\mathbf{0 . 0 5}$.

$\dagger$ Values in parentheses are standard error of the mean $(n=36)$.

† N-acetyl glucosaminides. 


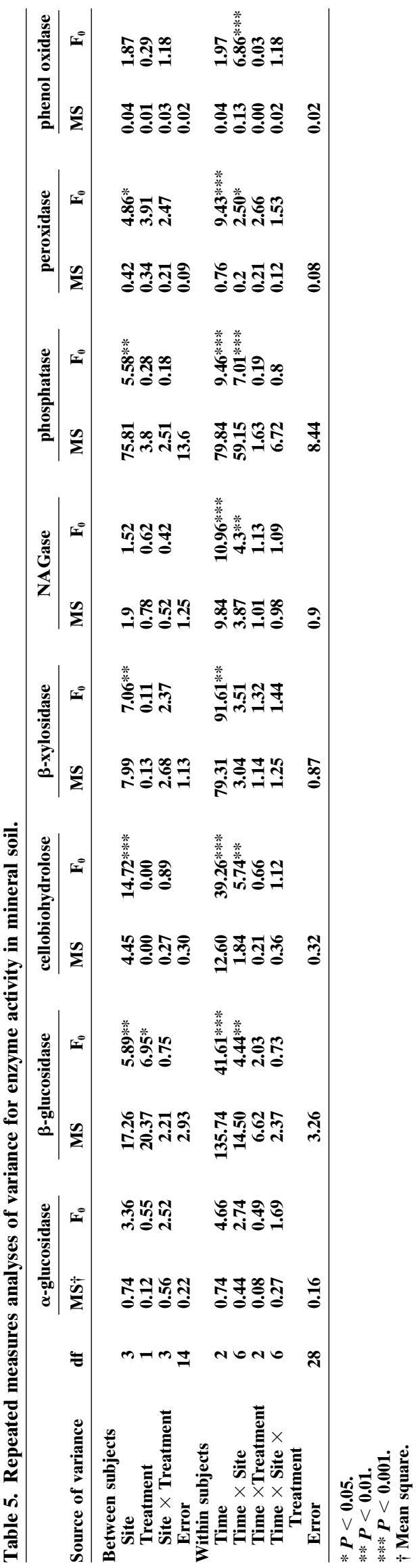

may reduce the complete degradation of lignin and cellulose by soil microbial communities. Such a response has the potential to diminish the physiological capacity of microbial communities to degrade plant litter.

Microbial biomass was significantly lower in plots receiving $\mathrm{NO}_{3}^{-}$additions (Fig. 4), and this response may result from an indirect impact $\mathrm{NO}_{3}^{-}$additions have on microbial $\mathrm{C}$ acquisition, and thus energy available for heterotrophic metabolism. Support for this idea comes from the reduction in $\beta$-glucosidase we consistently observed, an important enzyme in both early and later stages of cellulose degradation (Eriksson et al., 1990). Because cellulose is the most common organic substrate produced by plants (Eriksson et al., 1990), a reduction in the metabolism of this substrate could eventually impact the rest of the soil food web by reducing energy enzymatically derived from cellulose degradation. For example, a reduction in $\beta$-glucosidase activity will lower the physiological capacity of the microbial community to metabolize cellobiose (Deshpande et al., 1978). Moreover, lower rates of peroxidase in forest floor suggest a decline in ligninolytic activity, which also could reduce access to cellulose contained in lignified cell walls. Although we cannot draw causation for our results, declines in the activity of key degradative enzymes correspond with a reduction in microbial biomass.

The reduction in $\beta$-glucosidase activity may result from elevated polyphenol concentrations in soil, because high phenolic concentrations can inhibit $\beta$-glucosidase activity (Freeman et al., 2001). Our results suggest that the significant $54 \%$ decrease in litter phenol oxidase and $18 \%$ decrease in soil peroxidase activity could result in incomplete lignin degradation, which, in turn, could elevate soluble phenols in soil solution. Because phenol oxidase oxidizes the benzene ring in a phenolic compound (Hammel, 1997), and peroxidase has the ability to oxidize lignin macromolecules into simple phenols (Tien and Kirk, 1983), a reduction in the activities of these enzymes has the potential to increase the concentration of soluble phenolics. Results show that peroxidase activity was reduced more than phenol oxidase activity in $\mathrm{NO}_{3}^{-}$amended soils. Because peroxidase breaks lignin into soluble phenolics and phenol oxidase degrades soluble phenolics, then it stands to reason soluble phenolics would increase in concentrations under these circumstances. In our experiment, $\mathrm{NO}_{3}^{-}$additions significantly increased $(300 \%)$ the production of DOC from these same sites (Pregitzer et al., 2003). The increase in the leaching of DOC in our plots receiving $\mathrm{NO}_{3}^{-}$additions (Pregitzer et al., 2003) is consistent with the idea that higher soluble phenolics result from $\mathrm{N}$ additions. Nonetheless, it will be necessary to quantify soluble phenolic content in our experiment to determine if our contention is correct.

These observations give rise to a potential chain of events, which may cause a reduction in soil microbial biomass. An excess of inorganic $\mathrm{N}$ limits the ability of soil microorganisms to degrade lignin (Berg, 1986; Fog, 1988), which would promote incomplete lignin degradation and potentially the accumulation of soil organic matter (Berg and Tamm, 1991; Berg et al., 2001). A 


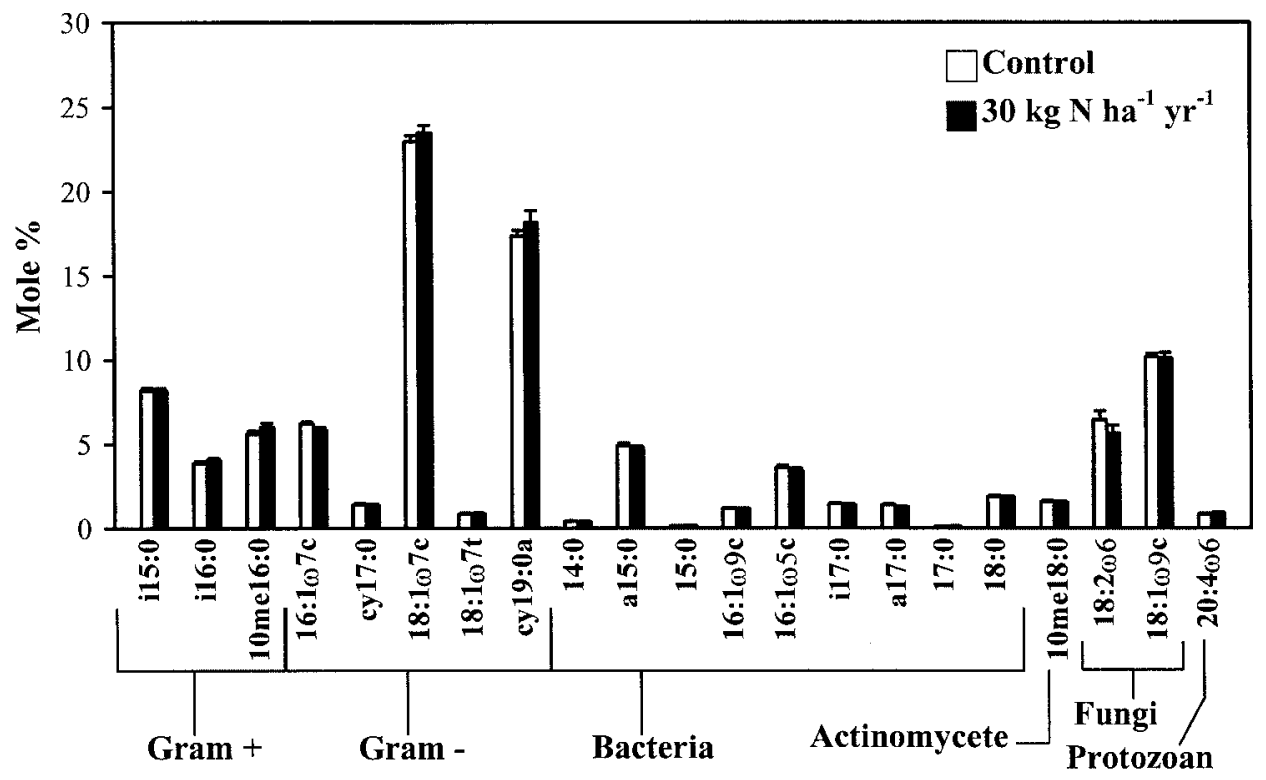

Fig. 4. The influence of $\mathbf{N}$ addition on microbial community composition in mineral soil. Error bars represent standard error of the mean $(n=36)$.

potential increase in the concentration of phenols, in turn, might inhibit $\beta$-glucosidase activity (Freeman et al., 2001). However, mean $\beta$-glucosidase activity during 1999 and 2000 at Site B, showed no response to our treatments (Saiya-Cork et al., 2002). Because DOC leaching also was higher in $\mathrm{N}$-amended plots at that time (Pregitzer et al., 2003), it is unlikely that elevated soluble phenolics, alone, were responsible for the reduction in $\beta$-glucosidase we observed. Alternatively, the reduction in $\beta$-glucosidase activity could be due to a decrease in available cellulose due to lower rates of lignin metabolism (Eriksson et al., 1990). However, if this scenario were important, then cellobiohydrolase and $\beta$-xylosidase activities would have likely exhibited larger declines in activity than we observed (Table 4). Our data do not allow us to discern which of these alternatives was the primary mechanism responsible for the reduction of $\beta$-glucosidase activity or whether a decline in $\beta$-glucosidase was responsible for the reduction in microbial biomass. Answering these questions will be an important part of understanding the indirect impact anthropogenic $\mathrm{NO}_{3}^{-}-\mathrm{N}$ has on northern hardwood ecosystems.

One might argue that the decrease in microbial biomass was caused by an increase in the ionic strength of soil due to the application of $\mathrm{NaNO}_{3}$. Increases in ionic strength can lower soil osmotic potential, which could reduce the availability of water to microbial communities and lower their biomass. Since the start of the fertilization, we have added nearly $400 \mathrm{~kg} \mathrm{ha}^{-1}$ of $\mathrm{Na}$ along with $270 \mathrm{~kg} \mathrm{ha}^{-1}$ of $\mathrm{N}$. Increases in ionic strength $>2$ $\mathrm{dS} \mathrm{m}{ }^{-1}$ can decrease acid phosphatase and $\alpha$-glucosidase enzyme activities (Frankenberger and Bingham, 1982; Garcia and Hernandez, 1995). However, we did not find a significant decrease in acid phosphatase or $\alpha$-glucosidase in the fertilized plots (Table 4). Moreover, mean electrical conductivity was $0.14 \mathrm{dS} \mathrm{m}^{-1} \pm 0.06$ in both control and in $\mathrm{NO}_{3}^{-}$-amended plots $(10 \mathrm{~cm})$ for all sites and times (J. DeForest, unpublished data, 2002).
In summary, it does not seem likely that the application of $\mathrm{Na}$ in the $\mathrm{NaNO}_{3}$ was a determining factor in the change of microbial biomass or microbial community function.

In conclusion, a substantial increase in the atmospheric deposition of $\mathrm{NO}_{3}^{-}$had a noticeable influence on ecosystem processes that are mediated by microbial communities. Our results suggest that excess $\mathrm{NO}_{3}^{-}$alters microbial community function by suppressing the activity of enzymes responsible for cellulose and lignin degradation. Although we found no evidence that microbial community composition was altered by $\mathrm{NO}_{3}^{-}$addition, microbial biomass decreased significantly. Our results suggest that anthropogenic $\mathrm{NO}_{3}^{-}$may alter decomposition processes in forest ecosystems by diminishing the physiological capacity of soil microbial communities to degrade plant litter.

\section{ACKNOWLEDGMENTS}

This research was supported by the National Science Foundation grant DEB 0075391. Thanks to Matt Tomlinson for site maintenance. We acknowledge the USDA Forest Service and the Michigan DNR for providing study site locations

\section{REFERENCES}

Aber, J., W. McDowell, K. Nadelhoffer, A. Magill, G. Berntson, M. Kamakea, S. McNulty, W. Currie, L. Rustad, and I. Fernandez. 1998. Nitrogen saturation in temperate forest ecosystemsHypothesis revisited. Bioscience 48:921-934.

Boxman, A.W., K. Blanck, T.E. Brandrud, B.A. Emmett, P. Gundersen, R.F. Hogervorse, O.J. Kjonaas, H. Persson, and V. Timmermann. 1998. Vegetation and soil biota response to experimentallychanged nitrogen inputs in coniferous forest ecosystems of the NITREX project. For. Ecol. Manage. 101:65-79.

Berg, B. 1986. Nutrient release from litter and humus in coniferous forest soils-A mini review. Scandinavian J. For. Res. 1:359-369.

Berg, B., and C.O. Tamm. 1991. Decomposition and nutrient dynamics of litter in long-term optimum nutrient experiments. Scandinavian J. For. Res. 6:305-321.

Berg, B., AV. DeSanto, C. McClaugherty, and D. Johnson. 2001. 
Humus buildup in boreal forests: Effects of litter fall and its $\mathrm{N}$ concentration. Can. J. For. Res. 31: 988-998.

Burton, A.J., K.S. Pregitzer, and N.W. MacDonald. 1993. Foliar nutrients in sugar maple forests along a regional pollution-climate gradient. Soil Sci. Soc. Am. J. 57:1619-1628.

Carreiro, M.M., R.L. Sinsabaugh, D.A. Repert, and D.F. Parkhurst. 2000. Microbial enzyme shifts explain litter decay responses to simulated nitrogen deposition. Ecology 81:2359-2365.

Deshpande, V., K. Eriksson, and B. Pettersson. 1978. Production, purification and partial characterization of 1,4-beta-glucosidase enzymes from Sporotrichum-pulverulentum. Eur. J. Biochem. 90: 191-198.

Dix, N.J., and J. Webster. 1995. Fungal Ecology. p 48-52. Chapman \& Hall, Boca Raton, FL.

Eriksson, K.E., R.A. Blanchete, and P. Ander. 1990. Microbial and enzymatic degradation of wood components. Springer-Verlag, Berlin.

Fenn, M.E., M.A. Poth, J.D. Aber, J.S. Baron, B.T. Bormann, D.W. Johnson, A.D. Lemly, S.G. McNulty, D.F. Ryan, and R. Stottlemyer. 1998. Nitrogen excess in North American ecosystems: Predisposing factors, ecosystems responses, and management strategies. Ecol. Appl. 8:706-733.

Fog, K. 1988. The effect of added nitrogen on the rate of decomposition of organic matter. Biol. Rev. 63:433-462.

Frankenberger, W.T., and F.T. Bingham. 1982. Influence of salinity on soil enzyme activities. Soil Sci. Soc. Am. J. 46:1173-1177.

Freeman, C., N. Ostle, and H. Kang. 2001. An enzymic 'latch' on a global carbon store. Nature 409:149.

Galloway, J.N. 1998. The global nitrogen cycle: Changes and consequences. Environ. Pollut. 102:15-24.

Galloway, J., G.E. Likens, and M.E. Hawley. 1984. Acid precipitationnatural versus anthropogenic components. Science 226:829-831.

Garcia, A., and T. Hernandez. 1995. Influence of salinity on the biological and biochemical activity of a calciorthird soil. Plant Soil 178:225-263.

Guckert, J.B., C.P. Antworth, P.D. Nichols, and D.C. White. 1985. Phospholipid, ester-linked fatty acid profiles as reproducible assays for changes in prokaryotic community structure of estuarine sediments. FEMS Microbiol. Ecol. 31:147-158.

Gundersen, P., B.A. Emmett, O.J. Kjonaas, C.J. Koopmans, and A. Tietema. 1998. Impact of nitrogen deposition on nitrogen cycling in forest: A synthesis of NITREX data. For. Ecol. Manage. 101:37-55.

Hammel, K.E. 1997. Fungal degradation of lignin. p. 33-46. In G. Cadisch and K.E. Giller (ed.) Driven by nature, plant litter quality and decomposition. CABI, Wallingford, UK.

Keyser, P., T.K. Kirk, and J.G. Zeikus. 1978. Ligninolytic enzyme system of Phanerochaete chrysosporium: Synthesized in the absence of lignin in response to nitrogen starvation. J. Bacteriol. 135:790-797.

MacDonald, N.W., D.R. Zak, and K.S. Pregitzer. 1995. Temperature effects on kinetics of microbial respiration and net nitrogen and sulfur mineralization. Soil Sci. Soc. Am. J. 59:223-240.

Pregitzer, K.S., D.R. Zak, A.J. Burton, and J.A. Ashby. 2003. Chronic nitrate additions dramatically increase the export of carbon and nitrogen from northern hardwood ecosystems. Biogeochemistry in press.

Saiya-Cork, K.R., R.L. Sinsabaugh, and D.R. Zak. 2002. The effects of long term nitrogen deposition on extracellular enzyme activity in an Acer saccharum forest soil. Soil Biol. Biochem. 34:1309-1315.

Tien, M., and T.K. Kirk. 1983. Lignin-degrading enzyme from the hymenomycete Phanerochaete chrysosporium Burbs. Science 221: 661-663.

Tunlid, A., and D.C. White. 1992. Biochemical analysis of biomass, community structure, nutritional status, and metabolic activity of microbial communities in soil. p. 229-262. In J. Bollag, and G. Stostky (ed.) Soil Biochemistry. Vol. 7. Marcel Dekker, New York.

Vestal, J.R., and D.C. White. 1989. Lipid analysis in microbial ecology. Bioscience 39:535-541.

Vitousek, P.M., H.A. Mooney, J. Lubchenco, and J.M. Melillo. 1997. Human domination of Earth's ecosystem. Science. 277:494-499.

White, D.C., W.M. Davis, J.S. Nickels, J.D. King, and R.J. Bobbie. 1979. Determination of the sedimentary microbial biomass by extractible lipid phosphate. Oecologia 40:51-62.

Zogg, G., D.R. Zak, K.S. Pregitzer, and A.J. Burton. 2000. Microbial immobilization and the retention of anthropogenic nitrate in a northern hardwood forest. Ecology 81:1858-1866. 